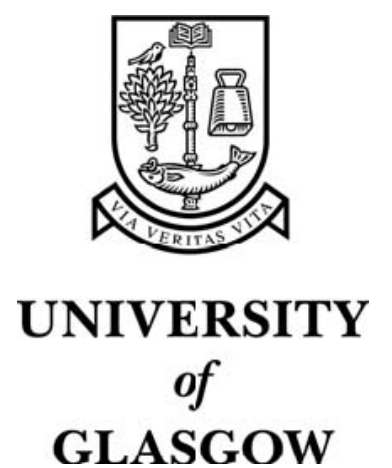

Bishop, P. and Jansen, J. D. (2005) The geomorphological setting of some of Scotland's east coast freshwater mills: a comment on Downward and Skinner (2005) 'Working rivers: the geomorphological legacy...'. Area 37(4):pp. 443-445.

http://eprints.gla.ac.uk/3396/ 
Bishop P, Jansen JD (2005). The geomorphological setting of some of Scotland's east coast freshwater mills: a comment on Downward and Skinner (2005) 'Working rivers: the geomorphological legacy...'. Area, 37.4, 443-445.

\title{
The geomorphological setting of some of Scotland's east coast freshwater mills: a comment on Downward and Skinner (2005) 'Working rivers: the geomorphological legacy ...'
}

\author{
Paul Bishop and John D Jansen \\ Department of Geographical and Earth Sciences, University of Glasgow, Glasgow G12 8QQ \\ Email: pbishop@ges.gla.ac.uk
}

\begin{abstract}
Many of the water mills on Scotland's east coast streams, unlike those discussed recently by Downward and Skinner (2005 Area 37 138-47), are found in predominantly bedrock reaches immediately downstream of knickpoints (i.e. bedrock steps). Bedrock knickpoints in the lower reaches of Scottish rivers are a widespread fluvial response to the glacioisostatic rebound of northern Britain. These steps in the river profile propagate headward over time, but for intervals of a few centuries or so they are sufficiently stable to be exploited for the elevational fall necessary to power the mill wheel. Many of these mills were apparently powered by 'run-of-the-river', as are some today that formerly had mill dams. The typical lack of sediment storage along the erosional lower reaches of many Scottish rivers means that failure of mill structures in Scotland will probably have less dramatic geomorphological and management implications than those suggested by Downward and Skinner for southern English rivers.
\end{abstract}

Key words: Scotland, water mills, knickpoint, bedrock river, glacio-isostatic rebound

\section{Background}

Downward and Skinner's (2005) discussion of the fluvial geomorphological legacy of water mills addressed the management implications of a longstanding anthropogenic presence on the rivers of England. In this note, we extend Downward and Skinner's discussion by examining the situation of some water mills in the coastal streams of eastern Scotland. Our conclusions for this Scottish context differ from those of Downward and Skinner, not because we wish to disagree with their conclusions, but because of the fundamentally different topographic and tectonic settings of mills on Scotland's coastal streams.

Early water mills in Scotland were powered by placing a horizontal mill wheel directly into the flow of the stream (Gauldie 1981); this arrangement suited small, steep watercourses in Scotland (Shaw 1984). Alternatively, a vertical mill wheel was placed into the stream (in which case it is termed an undershot wheel). However, both of these early methods use only the force of the running water and are less efficient than a system that exploits the 
weight of falling water (Gauldie 1981; Shaw 1984). This more efficient form of the vertical mill wheel requires water to be delivered at least some way up the wheel (breastshot) or, ideally, to the top of the wheel (overshot and pitchback) to utilize the falling water's weight. Thus a key issue in siting a mill with an efficient vertical mill wheel is the provision of water at some elevation above the bottom of the mill wheel.

Downward and Skinner (2005) illustrated the lifting of the water level to the top of the mill wheel via an impoundment structure forming the mill pond, and the feeding of this elevated water directly to the mill wheel. Such damming is not necessary, however, where a steep channel gradient or step in the longitudinal profile provides sufficient elevation not too far upstream of the mill for water to be drawn off the stream and channelled around the contour to the wheel via a lade (Scottish term; English 'leat'). This run-of-the-river arrangement, termed in Scotland a 'burn mill' (Shaw 1984), did not make dams redundant (not least because of the need to cope with low flows in summer), but it did favour sites where the elevational fall in water was available, along with adequate year-round flow (a condition often met in the Scottish highlands and in the west). Moreover, many mills may not have required year-round operation. For example, after the repeal of the corn laws a small corn mill in Baldernock, about $2.5 \mathrm{~km}$ east of Milngavie near Glasgow, was converted to saw-milling in the late nineteenth century. At about the same time, the wall of the mill dam was breached in a flood, but the mill continued to operate successfully using a water off-take from run-of-the-river flows. This water off-take is situated upstream, towards the top of a bedrock step in the river's longitudinal profile, a situation that is common for Scottish mills and different from that described by Downward and Skinner (2005).

\section{Water mills and bedrock knickpoints in Scotland's east coast rivers}

The common presence of bedrock steps (or knickpoints) in Scottish rivers reflects several factors, two of which are related to the former glaciation of northern Britain. Note that these bedrock knickpoints are distinct from the alluvial knickpoints described by Downward and Skinner (2005) inasmuch as the bedrock knickpoints evolve far more slowly. In formerly glacierized valleys, bedrock steps (or riegels - Benn and Evans 1998) may be the result of sub-glacial erosional processes related to ice-erosion dynamics or simply the presence of resistant bedrock. Likewise, in non-glaciated valleys, knickpoints often develop where the river meets a band of resistant rock. Such 'lithological knickpoints' remain essentially stationary over time. A third kind, a 'propagating knickpoint', is triggered by base-level fall and retreats headward over time. Bishop et al. (2005) investigated such propagating knickpoints in Scotland's east coast rivers arising from the glacioisostatic rebound (surface uplift) of much of northern Britain since the melting of the last ice sheet. The ongoing surface uplift has triggered knickpoint propagation at rates of $\sim 10^{0}$ to $10^{2} \mathrm{~mm} /$ year from the point of relative base-level fall at the coast. Knickpoint propagation distance is scaled to the stream's catchment area by a simple power function, suggesting that river discharge (for which catchment area is a standard surrogate) exerts a fundamental control on knickpoint retreat: knickpoints in large rivers are found farther upstream than those in small rivers. Interestingly, essentially the same power function relationship applies to rivers in the west of Scotland, despite their much higher discharge per unit catchment area (Jansen et al. 2004). We interpret this to mean that discharge (and more so catchment area) represent only partial controls on knickpoint retreat, along with lithology, channel gradient, width and the nature of the bed material.

Two points from our work are relevant to Downward and Skinner's (2005) paper. Firstly, most old mills on the 20 Scottish streams examined in Bishop et al. (2005) are located immediately downstream of a bedrock knickpoint that provides the elevation to bring water to the top of the mill wheel. Multiple knickpoints in the larger coastal streams, reflecting multiple incisional waves triggered by ongoing surface uplift, commonly permitted mills to be established successively along these streams' lower reaches. The lack of erosive power in smaller streams tends to produce a steep, convex-up, lower reach of coalesced (or aggregated) knickpoints capable of only minimal headward retreat (Jansen et al. 2004; Bishop et al. 2005). Small streams therefore have fewer mills.

Secondly, because the lower reaches of many Scottish rivers are at or close to bedrock, reflecting the incision of the coastal rivers into the isostatically rising landmass, failure of these Scottish mill structures may have less dramatic geomorphological and management implications than those suggested by Downward and Skinner for southern English streams. 
Broadly speaking, just as northern Britain has undergone glacio-isostatic uplift, distant flexural isostatic effects have caused subsidence in the south (Lambeck 1995). Hence, unlike in our Scottish examples, thick sedimentation characterizes lower reaches of many English rivers and, as Downward and Skinner noted, base-level perturbations due to mill dam failure could initiate significant erosion of valley fills in the English case.

The failure of any mill dam and subsequent mobilization of sediment trapped in the dam will inevitably increase sediment loads downstream. However, the small size of most mill dams means that they generally have low sediment-trap efficiency (Brune 1953; Heinemann 1984), and that most sediment delivered to the mill dam is routinely flushed through during periodic floods. For example, the trap efficiency of the Baldernock mill dam referred to above is an extremely low 5-10 per cent, which is ideal for avoiding dam sedimentation and the need for frequent dredging. Low trap efficiency means that sediment slugs released as a result of mill dam failure may not greatly exceed the prefailure, flood-related sediment flux. Such sediment is therefore unlikely to constitute too severe a management problem.

\section{Acknowledgements}

Our Scottish knickpoint research is supported by the Royal Academy of Engineering (Anglo-Australian Postdoctoral
Fellowship to Jansen) and NERC grant NE/C510416/1. We thank Leah Gibbs for alerting us to Downward and Skinner's paper.

\section{References}

Benn D I and Evans D J A 1998 Glaciers and glaciation Arnold, London

Bishop P, Hoey T B, Jansen J D and Artza I L 2005 Knickpoint recession rates and catchment area: the case of uplifted rivers in Eastern Scotland Earth Surface Processes and Landforms 30 767-78

Brune G M 1953 Trap efficiency of reservoirs Transactions American Geophysical Union 34 407-18

Downward S and Skinner K 2005 Working rivers: the geomorphological legacy of English freshwater mills Area 37 138-47

Gauldie E 1981 The Scottish country miller 1700-1900: a history of water-powered meal milling in Scotland Donald, Edinburgh

Heinemann H G 1984 Reservoir trap efficiency in Hadley $\mathbf{R}$ F and Walling D E eds Erosion and sediment yield: some methods of measurement and modelling Geo Books, Norwich 201-18

Jansen J D, Bishop P and Hoey T B 2004 Controls on knickpoint evolution in east and west Scotland Geophysical Research Abstracts 606513 General Assembly of the European Geosciences Union, Nice, France 25-30 April 2004

Lambeck K 1995 Late Devensian and Holocene shorelines of the British Isles and North Sea from models of glacio-hydroisostatic rebound Journal of the Geological Society, London 152 437-48

Shaw J 1984 Water power in Scotland 1550-1870 Donald, Edinburgh 